\title{
Athens and Delphi in the Classical Period: Exploring a Religious Relationship
}

\author{
Hugh Bowden ${ }^{1}$ (1)
}

Received: 3 August 2020 / Accepted: 11 August 2020 / Published online: 28 August 2020

(C) The Author(s) 2020

\begin{abstract}
In this article, I present an interpretation in religious terms of what Athenians were doing when they went to Delphi as representatives of their city. I begin by briefly outlining the key moments of Athenian involvement with Delphi in the classical period, which is roughly from 479 to $338 \mathrm{BCE}$, and the general relationship between city and sanctuary. I then look at the activities of the Athenian delegates to the Delphic Amphiktyony, whose responsibilities included representing the city of Athens at the festival of the Pylaia at Anthela and offering sacrifice at Delphi. I then turn to sacred ambassadors coming to consult the oracle, and show that occasions of consultation were festival occasions and that the experience of the theoroi was profoundly religious. I demonstrate that more than any immediate political concerns, maintaining a good relationship with Apollo was central to these activities. Evidence will be drawn largely from inscriptions from Delphi and literary sources from Athens, dating to the period under investigation.
\end{abstract}

Keywords Athens · Delphi · Delphic oracle $\cdot$ Divination · Greek religion

\section{Introduction}

Studies of the relationship between Athens and Delphi usually focus on two important institutions: the Delphic oracle and the Delphic Amphiktyony, and tend to treat Athenian interest in both of them as fundamentally political (e.g. Hornblower 2007; Bowden 2005). However, both of these institutions are associated with the temple and sanctuary of Apollo Pythios at Delphi and are therefore very much religious institutions: the relationship between Athens and Delphi was importantly the relationship between a community and a god. In this article, I will explore the implications of this for our interpretation of what Athenians were doing when they went to Delphi as theōroi, sacred ambassadors for their city. I will begin by briefly outlining

Hugh Bowden

hugh.bowden@kcl.ac.uk

1 Department of Classics, King's College London, London WC2R 2LS, UK 
the key moments of Athenian involvement with Delphi in the classical period, which is from the time of the Persian invasions of Greece in the early fifth century BCE until the defeat of Athens at Chaironeia in 338 BCE. I will then look at the activities of the Athenian delegates to the Delphic Amphiktyony, whose responsibilities included representing the city of Athens at the festival of the Pylaia at Anthela and offering sacrifice at Delphi. I will then turn to theorroi coming to consult the oracle, and show that occasions of consultation were festival occasions and that the experience of the theorroi were profoundly religious. I will demonstrate that more than any immediate political concerns, maintaining a good relationship with Apollo was central to these activities. ${ }^{1}$

Athenians had been involved with Delphi in the sixth century: Solon, to whom the laws of Athens were attributed, is said to have been involved in the 'First Sacred War' early in that century, although the tradition of that war needs to be treated with great caution (Robertson 1978; Hall 2014: 312-325). Later in the century, the genos of the Alkmaionidai, who were in exile from Athens at the time, paid for the reconstruction of temple of Apollo after it burned down, according to Herodotus (5.62). The Athenian treasury, dating from the late sixth or early fifth century, is the earliest monumental symbol of the involvement of the city of Athens with the site. This was followed by the Athenian Stoa further along the sacred way and by the group of statues constructed in the $460 \mathrm{~s}$, the base of which now stands by the treasury. All these were dedications from the spoils of war after victories against the Persians, the Stoa housing the ropes captured at Sestos from the bridges over the Hellespont. The date of the treasury and therefore the occasion for its creation are less certain, but its function was to hold subsequent smaller dedications to the god made by Athenians. These dedications served two purposes which should not be disentangled. They were gifts made to the god in recognition of and thanks for his contribution to the Athenian victories, and they were monuments to Athenian success that would be witnessed by all the visitors walking up the sacred way to the temple, the theatre and beyond (Scott 2010: 77-81). The message that the monuments projected was that Athens was powerful, successful and wealthy and also that the city had a close relationship with Apollo. Displays of this kind in the sanctuary were aspects of the competition for prestige in which Greek cities were constantly engaged. Success in battle, particularly against non-Greek enemies, was something to celebrate in the same way as victories in the Pythian Games might be celebrated (Hornblower 2010: 57-58).

In the middle of the fifth century, Athens was involved in the conflict referred to by Thucydides (1.112.5) as the 'so-called Sacred War' and known to modern scholars as the Second Sacred War. The conflict concerned whether or not Delphi should be a member of the Phokian koinon, the group of cities identifying

\footnotetext{
1 One important element of religious activity at Delphi, the Pythian Games, will not be discussed here. The festival was an occasion at which leaders of communities might display their own wealth and power, and their respect for Apollo, either by the celebration of victories in the games, or by presiding over the festival, engaging with what Leslie Kurke (1993) has called 'The economy of kudos'. There is too little evidence for a discussion of Athenian engagement with the Pythian Games to add to my overall argument.
} 
as Phokian. This group had a common sanctuary, the Phokikon, and sometimes engaged in common military action, as it did in the middle of the fourth century, in the so-called Third Sacred War (McInerny 1999: 154-185). Delphi's position in relation to the other Phokian cities was distinctive in two respects: it was separated from the other Phokian cities geographically by Mount Parnassos, and the wealth of the sanctuary of Apollo was much greater than that of any other sanctuary in the region. The separation of Delphi from the koinon was considered beneficial by the Boiotians and their allies the Spartans; for this reason, the Athenians supported the Phokians. The fact that the conflict was referred to at the time as the 'Sacred War' (hieros polemos) indicates that for some observers at least, this was a war concerned with the sanctuary of Apollo and was therefore fundamentally about religious matters. Plutarch (Pericles 21) adds the significant detail that it was as a result of these events that the Spartans and Athenians were honoured with grants of promanteia at Delphi, which is the right to consult the oracle before less favoured cities. In the Peloponnesian War, when the Athenians and the Spartans agreed first a truce, and then a peace treaty, the question of access to the sanctuary and oracle of Apollo and the autonomy of the city of Delphi were the first items mentioned (Thucydides 4.118, 5.18; Bowden 2005: 134-139). Athens was involved in Delphic factional fighting again in the fourth century, when in 363 BCE the city granted citizenship to a group of men exiled from Delphi, led by Astykrates (Inscriptiones Graecae (IG) $\mathrm{ii}^{2}$ 109). As Hornblower (2007: 45-46) shows, Astykrates and his companions were pro-Phocian and were active back in Delphi in the subsequent period of Phokian control. And Athenians were involved in the events which triggered the so-called Fourth Sacred War of 339 $\mathrm{BCE}$, which we will discuss in greater detail later.

Delegates sent to sanctuaries were called theōroi, a term translated by Rutherford (2013) as 'state pilgrims and sacred observers'. The earliest known use of the word theorros in Greek literature refers to someone whose role is to consult the Delphic oracle:

A man who is a theōros must take care, Cyrnus, to be straighter than a carpenter's compass, rule, and square, that man to whom the priestess of the god at Delphi in her response reveals the god's voice from the wealthy shrine. (Theognis 1.805-808)

But the word, and the related term for a sacred embassy, theōria, could refer to people sent to sanctuaries for a wider range of purposes. In the fifth and fourth centuries, the Athenians sent a number of theóriai to Delphi (Parker 2007: 82-87). These included the Thyiades, women from Athens and Delphi who travelled each year to Mount Parnassos to engage in ecstatic ritual activity in honour of Apollo and Dionysus (McInerney 1997; Versnel 1998: 137-138). Less frequent was the Pythaiis, which took place at uncertain intervals: we know of three occasions from the fourth century (Parker 2007: $86 \mathrm{n}$. 28). When it was marked, the Athenians sent gifts to Apollo, accompanied by a delegation that included important officials as well as choruses to perform at Delphi: the festival was revived on a very grand scale in the Hellenistic period (Rutherford 2013: 222-230). But the 
main reasons for which Athenian theōroi were sent to Delphi were to take part in the activities of the Delphic Amphiktyony, and to consult the oracle of Apollo Pythios, and these will be the focus of the rest of this paper.

\section{The Delphic Amphiktyony}

Athens had an important relationship with the sanctuary of Apollo at Delphi through its representation in the Delphic Amphiktyony (Lefèvre 1998; Sánchez 2001). Our information about the structure of the Amphiktyony before its reorganisation in 346 $\mathrm{BC}$ is limited. It was a group of communities which sent representatives twice a year to Thermopylai and Delphi. In the period after 346, there were 12 named communities, each of which supplied two voting delegates, known as hieromnemones, with each hieromnēmōn accompanied by three pylagorai. For Athens, the hieromnēmōn was selected by lot, as was normal for those who represented the Athenian demmos, while the pylagorai were elected, which indicates that they were chosen on the basis of their expertise. The Athenians sent representatives as one of the two delegations of Ionians. This was an arrangement that had probably been gradually formalised in the period before 346, and we should assume that the nature of the Amphiktyony had evolved to some extent at least over the period of its existence (Bowden 2003).

An important, but incomplete, inscription from Athens [Corpus des Inscriptions de Delphes (CID) 4.1] from the early fourth century sets out the body's responsibilities. It was responsible for the fabric of the sanctuary, for the roads giving access to it, for the uncultivated tract of land in the plain below the city running up to the border with Amphissa which was owned by the god and for the Pythian Games. We will consider some elements from this document below. Numerous other inscriptions survive, most of which are financial, and many of which relate to the project of rebuilding the temple of Apollo, which was destroyed in an earthquake in 373 BCE. These financial documents have been used by scholars to work out when, and for how long, meetings of the Amphiktyony took place, and they can supply incidental information about what the meetings involved (Lefèvre 1991).

The Amphiktyony met twice a year, in spring and autumn, and the inscriptions refer to these occasions as Pylaia. Scholars working on the Amphiktyony focus on the business meetings, with statements such as, 'la Pylée étant en fait le nom de l'assemblée des délégués amphictioniques' (Lefèvre 1991: 588). However, this can be misleading. The Pylaia was primarily a festival in honour of Demeter, held at Anthela, near Thermopylai, which the communities of the Amphiktyony celebrated together. Herodotus (7.200.2) describes the meeting place, where there were temples of the hero Amphiktyon and Demeter Amphiktyonis, and seats for the Amphiktyonic delegates. In Lysistrata (1129-1132), Aristophanes refers to the Pylaia alongside the Olympic Games as an occasion where Athenians and Spartans sacrificed together, and Sophocles, in Trachiniae (639), describes it as a celebrated meeting place of the Greeks. Strabo (9.3.7) also gives a description emphasising the festival's role as a meeting place. Herodotus also says (7.213.2) that it was at a meeting of the Amphiktyons there that the pylagorai passed judgment against Epialtes, the man accused of betraying the Spartans at the battle of Thermopylai. He does 
not mention the hieromnemones, and it is possible that, as their name suggests, it was the pylagorai who were actively involved in events at Thermopylai, while the hieromnemones had the principal responsibility at Delphi, where the pylagorai were not part of the decision-making process, as Aischines (3.117) indicates.

Those who came to take part would need places to sleep, water for drinking and washing and no doubt other entertainment. We can see how these matters might be organised from a later inscription relating to a different festival, the Mysteries of the Great Gods of Andania, from 91 BCE (Gawlinski 2012). The regulations have quite a lot to say about practical matters for making sure that visitors can be properly accommodated. They include restrictions on the size and furnishing of tents, rules about water supply and the collection of firewood, controls on the price of baths and the provision of a market in a defined area. The inscription reminds us how much a festival involved the commercial world of traders and service providers alongside the religious elements. A similar picture comes from Pausanias' description of a festival of Isis at Tithorea (10.32.15), not far from Delphi, where he mentions the sale of slaves, livestock, clothes and silver and gold. As De Ligt (1993: 38-39) says of the Roman period: "many periodic festivals were accompanied by commercial activities of one kind or another, and it seems likely that many accessory festal markets developed into "genuine fairs", and a similar conclusion about classical and Hellenistic Greece is reached by Christophe Chandezon (2000). That the Pylaia was such a festival is clear from the fact that the word pylaia could mean a 'farrago', and pylaiastai were 'buffoons' or 'mountebanks', which are the kind of people who hang around at fairs (Bowden 2003: 68).

Having celebrated the festival in their seats of honour, the Athenian delegation would have travelled on to Delphi, accompanied no doubt by the entertainers and traders who had gathered at the Pylaia. As at the Pylaia and other festivals, there was a need for places where visitors to the sanctuary could stay, and facilities to make sure that they could wash and drink and eat. At Delphi, it is clear that the sacred land left uncultivated for Apollo was used as camping ground when the sanctuary was busy. The part of the Athenian inscription recording the Amphiktyonic oath that refers to the sacred land (CID 4.1.22) mentions porticos (pastades) that were to be available to anyone, presumably as shelters. This area of land was presumably also where visitors might pitch their own tents. In Euripides' Ion (1132-1165), a messenger describes a grand open-sided tent built by Ion on behalf of Xouthos in which the people of Delphi would be invited to dine. Times of consultation of the oracle were therefore occasions for reciprocal hospitality, honouring the citizens of Delphi as well as the god. While Xouthos' feast is no doubt part of the mythical world of the play, Delphic proxenoi would probably have been entertained by the individuals or city delegations to whom they offered their services.

There is no doubt that members of the Amphiktyony could use its meetings for a variety of purposes, and the hints in our sources about its significance in the politics and diplomacy of the Greek world in the fifth and fourth century have generated much debate (Lefèvre 2002: 437-443; Bowden 2003; Hornblower 2007; Buckler and Beck 2008). We have a detailed account of one meeting of the Amphiktyony at Delphi, reported by the Athenian politician Aischines, who was one of the Athenian pylagorai in spring $339 \mathrm{BCE}$. We also have an alternative 
account of the events, provided by Aischines' rival Demosthenes, who was not present. The meeting in spring 339 was probably not typical in terms of its consequences, but the accounts of it can give an indication of what was discussed. Broadly speaking, Aischines provides a 'religious' reading of the events, while Demosthenes offers a 'political' one. The speeches were delivered in $330 \mathrm{BCE}$, so were written with considerable hindsight.

For Demosthenes, the events of the meeting of Spring 339 are about realpoli$t i k$ : he constructs a story (18.141-152) telling how Aischines, bribed by Philip of Macedon, orchestrated events to present Philip with the opportunity to bring an army into central Greece. Although his account has nothing to say about religious obligations, it is worth noting that Demosthenes introduces it with an invocation of the gods, naming Pythian Apollo specifically, and calling on them to reward him if he speaks the truth and punish him if he brings false charges (141). After this, he describes the constraints Philip supposedly faced in carrying out any military action, and suggests that Philip was looking for a way to get the Amphiktyons to invite him to bring his army into Phokis. Philip could not have his own hieromnemones propose this without this arousing the suspicion of his opponents, the Thebans and Thessalians, which was why getting Aischines to do this was an obvious solution. Aischines then claimed (falsely according to Demosthenes) that the Amphissans were cultivating sacred land, deliberately provoking a reaction from the Amphissans, who seized a number of hieromnemones. As an inevitable consequence, the Amphiktyons (or a faction within the membership) voted to take military action against the Amphissans and to appoint Philip as leader of this campaign. The narrative focuses solely on relations between men: the gods are not relevant.

In contrast, Aischines (3.106-128), whose speech will have preceded Demosthenes', constantly emphasises religious obligation, introducing his account by saying that he will begin with Demosthenes' transgressions against the gods. He then goes on to explain the origins of the sacred land that the Amphissans were accused of cultivating with an account of the so-called First Sacred War which involves sacrilege, a curse, oaths and an oracle. He next narrates the events of the meeting of the Amphiktyons, where debate moved from the dedication by the Athenians of shields on the temple and accusations that the Athenians were polluted, to the supposed impiety of the Amphissans in cultivating the sacred land. Aischines describes how he invoked the Amphiktyonic oath, including the curse that would fall on anyone who broke the oath, and drew attention to the victims about to be sacrificed as part of the proceedings. This leads to the Amphiktyons and the men of Delphi attacking the Amphissans before been driven back, and then on the following day the calling of an ekklessia of the Amphiktyons, which Aischines explains as including anyone making a sacrifice in the sanctuary or consulting the oracle. The ekklessia determined that 'the hieromnemones should come to Thermopylai at a designated time before the Pylaia bringing a resolution indicating what penalty the Amphissans should pay for their crimes against the god, the sacred land and the Amphiktyons' (3.124). Aischines goes on to accuse Demosthenes of tricking the assembly into passing a decree that prevented the Athenian delegation from attending this meeting. He ends this part of his account by asserting that the gods had warned the Athenians 
to be on their guard and that Demosthenes had led the city to ruin by rejecting these warnings.

Presumably, these accounts were intended to sound plausible to the Athenian citizens to whom they were addressed: Athenian involvement in the Amphiktyony could be explained in more than one way. But Aischines' account can provide modern readers with a fuller understanding of the concerns of the Amphiktyons and can be backed up by evidence from the inscriptions. His concern for stopping any permanent occupation of the sacred land by the Amphissans is in line with the requirements of the Amphiktyonic oath (CID 4.1.21-26) which among other things forbade anyone to stay on the land for more than 30 days or to process grain for bread. He describes himself referring to the reed baskets and the victims prepared for sacrifice. Financial accounts for meetings of the Amphiktyons include costings for reed baskets, men to guard sheep and men to butcher and cook them for the sacrifice, and also for laurel wreaths for the delegates to wear at the sacrifice (e.g. CID 2.34 i.28-33, 57-63, ii.32-37, 46-53).

His description of the penalty fixed for those who have committed sacrilege and also for those who have failed to prevent it (of left it unpunished) is also important, as it is framed in religious terms: 'let them never sacrifice duly (hosioss) to Apollo or Artemis or Leto or Athena Pronaia, and may the gods not accept their offerings' $(3.111,121)$. A different version of this is the sanction announced by the herald on behalf of the Amphiktyons that would be imposed on any city whose delegates did not join the expedition against the Amphissans: 'let any city that is not present be excluded from the sanctuary, and be under a curse and bound for destruction' (3.122). While the latter elements of this sanction were in the hands of the gods, exclusion from the sanctuary was something that men would be expected to enforce, and it would be the Amphiktyons who would do this. Exclusion from Panhellenic sanctuaries was a sanction that was occasionally used and when applied to Greek cities was taken very seriously. A particularly striking case was the exclusion of the Spartans from Olympia at the time of the Olympic Games of $420 \mathrm{BCE}$ (Hornblower 2004: 273-286; Hornblower 2010: 196-212; Gribble 2012: 51-53). Thucydides (5.49-50) emphasises that all the other Greek states had sacred embassies (etheōroun) at the festival. Having been excluded from the festival, the Spartans sacrificed to Zeus 'at home' in Sparta. This indicates that the obligation to sacrifice to Zeus Olympios at the time of the festival remained even when the Spartans were not competing at the games. Rather than seeing the sacrifice as a preliminary to the games, the participants will have seen the games as a subsidiary activity after the sacrifice. All the Greek cities took part in the sacrifice, but only some in the games. Exclusion from the sanctuary of Delphi would have prevented a city from consulting the oracle (or participating in the Pythian Games), but also from sacrificing to Pythian Apollo at his principal sanctuary. Restoring free access to the sanctuary at Delphi is explicitly referred to in two treaties that were drawn up between the warring sides in the Peloponnesian War, in 423 and 421, and reported by Thucydides. The first clause of the first of these states: 'As to the sanctuary and the oracle (tou hierou kai tou manteiou) of Pythian Apollo, we are agreed that whoever wishes shall have access to it, without fraud or fear, according to ancestral custom' (Thuc. 4.118.1). The second, the Peace of Nicias, begins: 'Concerning the common 
sanctuaries, it shall be possible for anyone who wishes to sacrifice, travel, consult the oracle and send delegations (thuein kai ienai kai manteuesthai kai theōrein) according to ancestral practice by land and by sea without fear' (Thuc. 5.18.2). The terms of these treaties indicate that it was the full range of activities at sanctuaries that mattered to the Greek states potentially excluded from them (Bowden 2005: 136-139).

The issues discussed by the delegates to the meeting of 339 BCE may have had political and diplomatic implications, but they were debated as religious obligations to Apollo and his sanctuary. The sanctions that the Amphiktyons could impose on those who broke the rules, which included fines as well as exclusion from the sanctuary, were concerned with maintaining a good relationship with the god. And the discussions took place in order to establish that the men present had not committed impious acts, and were therefore able to join in the sacrifice that was the main purpose of the gathering. The broader context of the meeting was the celebration of festivals in honour of the gods, and much of the delegates' time will have been taken up in ritual activities, including sacrifices, and the feasting that inevitably accompanied it. This will have been true throughout the life of the Amphiktyony: to be a member of the theoria to the Pylaia at Anthela and Delphi was to honour Apollo.

\section{Consulting the Oracle}

We can now turn to the other element of the relationship between Athens and Delphi, the consultation of the oracle. This was only one of a number of ways in which the Athenian demos sought to establish the will of the gods. There were other oracular shrines outside Attika, including that of Zeus at Dodona and that of Ammon in Libya, as well as many less prestigious ones. There was an archive of oracles in Athens, which were to be consulted under certain circumstances. And there were manteis, who would accompany military commanders on campaign, but might serve under other circumstances. Given that there were these other options, it might seem that sending an embassy to Delphi was not a particularly convenient way of getting an answer to a pressing problem facing Athens. The oracle functioned 1 day a month for 8 months of the year. It is true that from the middle of the fifth century the Athenians had promanteia, but that would not guarantee that the oracle would provide answers to all the questions the Athenians might have. We have no idea how many questions any petitioner might ask of the oracle, but it is quite likely that they could consult only about a single issue. Probably, this would involve two questions of a standard form: 'would it be better and more profitable for us to do X?', and 'to what gods should we pray so that the action will produce the right result?' Herodotus (7.139.5-143) tells the famous story of the Athenian consultation about what they should do in the face of the Persian invasion of $480 \mathrm{BCE}$, and describes the theoroi returning later to get a second response. This story is probably very fictionalised, so cannot be relied upon as evidence for how consultations worked in the fifth century, but even if it were accurate, it does not show that multiple consultations, whether about the same or different topics were normal. We know of only 28 consultations of Delphi by the city of Athens in the period down to $300 \mathrm{BCE}$, of which nine are 
epigraphically attested (Bowden 2005: 168-169). For the period between the end of the Persian Wars and the death of Alexander the Great, leaving aside the examples rightly considered 'not genuine' by Fontenrose (1978), we have 14 responses, which are on average fewer than one a decade. While our evidence is certainly limited, we might expect rather more references to consultations of Delphi in the surviving literary and epigraphic sources if that was the Athenians' preferred means of establishing the divine will. But if the Athenians did not consult the oracle on all important matters, it does not follow that Pythian Apollo was not important to the Athenians. The authority of Apollo at Delphi was not limited to his providing specific answers to specific questions when consulted by Athenian theōroi. The Delphic responses in the Athenian archive could be cited as providing more general moral guidance (e.g. Demosthenes 21.51-2, 43.66), and other features of the sanctuary at Delphi could be cited as support for arguments about what to do, most obviously the various Delphic maxims that were engraved on the temple walls, at least by the fourth century (Morgan 2009).

Furthermore, it would have been understood that the Delphic oracle was not guaranteed to give reliable answers to all enquirers. In an interesting passage in the Homeric Hymn to Hermes, Apollo describes what the oracle would do for mortals:

As for humans, I shall harm one and profit another as I lead their countless peoples this way and that. He will profit from my utterance who comes on the cry or the flight of valid omen birds: that man will profit from my utterance, and I shall not deceive him. But he who puts his trust in birds of vain utterance, and wants to enquire after a prophecy beyond my intention, and to know more than the eternal gods, I declare he will journey for nothing, though I shall take his offerings. (Homeric Hymn to Hermes 541-9. Translation M.L. West)

Although Delphi is not named in the poem, it is clear that that is what is meant here. Apollo is saying that coming to Delphi to consult the oracle, and making the appropriate sacrificial offerings, is not enough to guarantee a reliable response. We may note that this characterisation of the potential unreliability of Delphic responses contrasts with that found in other texts; for example in the Homeric Hymn to Apollo, the god says 'and I would dispense unerring counsel to them all, issuing oracles in my rich temple' (292-293); Pindar says of the god, 'he does not engage in falsehoods' (Pythian 3.29); Aeschylus has Orestes talk of 'King Apollo, who was never before a false prophet' (Choephori 559); and the chorus in Euripides' Iphigeneia in Tauris refers to Apollo in Delphi, 'on his never-deceiving throne' (1254). Nonetheless, the Hymn to Hermes reflects an understanding of divination that we do find in other texts that the gods will not necessarily communicate with everyone. As Xenophon puts it in Cyropaedia (1.6.46):

The eternal gods know all things, both what has been and what is and what shall come to pass as a result of each present or past event; and if men consult them, they reveal to those to whom they are propitious what they ought to do and what they ought not to do. But if they are not willing to give counsel to everybody, that is not surprising; for they are under no compulsion to care for any one unless they will. (Translation W. Miller) 
Elsewhere Xenophon suggests that the gods are more likely to communicate with those who honour them with regular sacrifices (e.g. Hipparchicus 9.8-9; Memorabilia 1.4; see Bowden 2004). Although in principle any god might communicate with mortals, it is Apollo who is most associated with divination, and his sanctuary at Delphi would have been the most prestigious location associated with this activity. As we will see, when Athenian theōroi travelled to Delphi and consulted the oracle, this was only a small part of what they did there, and not necessarily the most important.

Delphi was not associated with oracular divination alone. It had many associations with other forms of divination, most notably the basic skills of all manteis, the interpretation of the actions of birds and the reading of the entrails of sacrificial victims. The passage from the Hymn to Hermes draws attention to both of these: first there is 'the cry or flight of valid omen birds' (phōnēi kai pterugessi telèentōn oiōnon) which apparently led the enquirers to the oracle, and then, the god says 'I shall take his offerings' (egō de ke dōra dekhoimēn), which may be taken to mean that the omens from the sacrifice are favourable. There were various ways in which a god might demonstrate that they rejected a sacrifice, most obviously through unfavourable omens, which might mean that the sacrifice was interrupted (for example by a bird stealing some of the entrails), or crucial organs were missing (Naiden 2013: 131-182). Apollo is here suggesting that he will accept sacrifices-that is, that the omens from them will be propitious - but that this will be no guarantee that the oracular response that follows will be reliable.

Modern accounts of consultations of Delphi tend to concentrate on the immediate circumstances of the consultant asking their question and the priestess replying (Amandry 1950; Parke and Wormell 1956: 1.17-45; Fontenrose 1978: 196-228; Compton 1994; Maurizio 1995; Bowden 2005: 17-25; Scott 2014: 9-24). But there was more to being a theōros than just this. The oracle at Delphi functioned on the seventh day of the month for eight months of the year. These days would have been major occasions in the life of the sanctuary, at which large numbers of visitors would have been present. As with the meetings of the Amphiktyony, we should understand these as festivals above all: celebrations of the god's appearance to mortals through the voice of his priestess.

The first month of consultation was Bysios, the eighth month of the Delphic year, which corresponded roughly to February - a time of year when, due to the weather, travelling to Delphi might not have been easy. Nonetheless, there is evidence that this was the occasion of a significant festival, the Theophania. Herodotus (1.51.1112) refers to a large silver mixing bowl, with a capacity of 600 amphorae (approximately 24,000 litres) which had been given to the god by Kroisos of Lydia in the sixth century, and which he says was used by the Delphians as a mixing bowl at the festival of the Theophania. This is the only definite reference from antiquity to a festival called Theophania at Delphi (Pfister 1934a; Petridou 2016: 276). We have a later reference to a festival of the same name on Chios, and it may have taken its name from the Delphic festival (Derow and Forrest 1982: 83-84; Garbrah 1986). A range of texts refer to the story that Apollo was absent from Delphi in the winter in the land of the Hyperboreans (Fontenrose 1959: 382-383, esp. n. 25). We know of a paian composed by Alkaios, describing the celebrations that attend Apollo's 
long-anticipated first arrival at Delphi from the land of the Hyperboreans (Himerius Or. 48.10-11 = Alcaeus Fr. 307c), and the Theophania would have been an obvious occasion for its first performance.

The Delphic month following Bysios was Theoxenios (Hannah 2005: 77-81), and this was named for another festival of Apollo that involved sacrifice and the distribution of meat, and to which Greek cities sent theōroi (Pfister 1934b; Jameson 1994). An inscription (Fouilles de Delphes 3 3.224.3) indicates that this was another occasion on which Kroisos' silver bowl would have been used. There is good reason to believe that the festival coincided with the functioning of the oracle. Another inscription, recording a convention between the people of Skiathos and Delphians, begins with matters relating to consulting the oracle, including a grant of promanteia, and the cost of the pelanos (the payment required for consulting the oracle). It goes on to mention what the Delphians will provide for the Skiathians including that the Delphians will give shares of the meat to the Skiathians at the Theoxenia (CID 1.13.27-29). This suggests that consulting the oracle and celebrating the Theoxenia might have taken place as part of a single theōria (Rutherford 2013: 196-198). Rutherford (2013: 244-245) identifies a theōria to the festival from Aigina, and there must have been others from across the Greek world. It is reasonable to suppose that if those communities wished to consult the oracle, they would send men to do that alongside those sent for the Theoxenia, if they were not in fact the same people.

The next month, Endyspoitropios, was the time of the spring Pylaia (Lefèvre 1991: 579-588). According to Aischines (3.124), there were people present at Delphi who had come to consult the oracle at the time when the Amphiktyons were meeting in spring 339, and this may well have been the case in most years. Although the Amphiktyons did not have direct responsibility for the oracle, it might be expected that the delegates would want to consult it, and arrange for their meeting and the functioning of the oracle to coincide. The autumn Pylaia was normally held in the month Boathoos, which was the final month in which the oracle operated. It is possible that this festival too coincided with the functioning of the oracle, although we know that the autumn Pylaia sometimes took place in the following month, Heraios.

It is likely that in all 8 months in which the oracle functioned, consultations of the oracle took place as part of a large festival. This would be one way in which consultation of the oracle differed from most other forms of divination, including many other oracular sanctuaries. Elsewhere, the process of divination took place at a time of the questioner's choosing, and the focus of the rituals would be their question. At Delphi, the theorros and his question took their place in the broader ritual. It is therefore worth exploring what Athenian theōroi to Delphi would have experienced when they came to consult the oracle.

Athenian theorriai to oracular sanctuaries in the fourth century were usually made up of a combination of representatives of the people chosen by lot, and experts, often chosen by election. ${ }^{2}$ The most detailed epigraphic account of Athenian planning for

\footnotetext{
${ }^{2}$ As well as the Amphiktyonic delegations, already mentioned, examples include the group of three men sent to consult the oracle of Amphiaraus at Oropos (Hyperides 4.14), one of whom, Euxenippos, was an acknowledged expert, and the group of four men asked to examine archived oracles in Athens in the late fifth century (IG I3 40.64-7), which included the oracle-interpreter Hierokles (Bowden 2019: 73-74).
} 
an embassy to the Delphic oracle states: 'the people shall choose three men, one from the Council and two from all Athenians, who will go to Delphi and ask the god ..' (IG $\left.\mathrm{ii}^{3} 1292.42-45\right)$. Although the inscription is not specific about how the three men were chosen, it is likely that at least one of them will have had experience of visiting Delphi. As is clear from Herodotus (7.141.1) and Euripides' Andromache (1103), those who were not Delphic citizens would have to be accompanied by Delphic proxenoi when they took part in ritual activity in the sanctuary. Proxeny ties were established in Delphi as in other cities, with individuals and their families developing ongoing relationships with particular cities, acting as the regular hosts of theōroi from those cities (e.g. $I G \mathrm{i}^{3} 27 ; I G \mathrm{ii}^{2} 51$ ). They would have accompanied the theōroi to the temple when they went to consult the oracle. The Athenian theoroi who came to Delphi regularly will have built up relationships with Delphic proxenoi, the men who accompanied them when they consulted the oracle. For others, Delphi would have been a place to explore. Since the time it took to travel to Delphi was unpredictable, delegations might arrive a few days before the day of consultation. Euripides, in his Ion (184-218) and Andromache (1086-1088), depicts visitors immediately after their arrival looking around at the sanctuary (the core meaning of the word theōros is 'observer'). To be a theōros was to engage fully with the sanctuary and everything that was going on in it.

Recognising the day of consultation as a festival occasion will change our understanding of the role of the theorroi. In his discussion of consulting the oracle, Michael Scott (2014: 15-17) presents their experience as rather tawdry and tedious: 'What followed then was a system of queuing... there was always a way to skip to the front... Once the order was decided, the money had to be paid... All this would take time, and consultants would be obliged to wait for long periods.' This underplays the solemnity and significance of the occasion. Rather, there would have been a procession through the sanctuary to the altar that stood in front of the temple. The theorroi would have accompanied the priestess to the temple, as Aeschylus (Eumenides 31-33) indicates. The order of the procession would have been fixed, with the priests and priestess of Apollo leading, along with other significant officials of the sanctuary. The theōroi would have their own order, with representatives of cities taking precedence over individual petitioners, and with representatives of the city of Delphi and those cities which had been granted the honour of promanteia going ahead of the others (Bowden 2005: 17). Within each category, the order would have been determined by lot (Eumenides 32). The procession itself would have been a visual display of the relationship between the communities whose representatives were present, and the god. To be near the front, as the Athenians would have been at least from the middle of the fifth century, would have been a sign of a close relationship between the city of Athens and Apollo. As the procession made its way along the sacred way through the sanctuary, it would also have passed the various monuments and treasuries erected by the Greek cities, the permanent reminders of the cities' ongoing relationship with the god. Each group of theorroi would have brought animals to sacrifice: a goat if they were consulting the oracle, and other victims 'in accordance with ancestral custom' (CID 1.13.19-24). Plutarch (Moralia 435b, $437 \mathrm{~b}$ ), referring to the practices of his own time, which may well have been the same as in the classical period, describes an initial sacrifice of a goat, which must 
shake all over when a libation is poured on it, to confirm that the day was propitious for the oracle. After that, other animals would be sacrificed by the Delphians and by the visiting theōroi. And only then would the theōroi be able to enter the temple with their proxenoi to consult the oracle. And after that, they would be able to eat the sacrificial meat, excluding those parts traditionally taken by the priests, as was normal practice at any sacrifice at a temple. In some cases, the visitors might be provided with a dining room to eat in, with wood for a fire, and salt and vinegar (CID 1.13.24-29) but in others they might eat in tents set up on the sacred land below the temple.

As we have seen in the case of Olympia and the Olympic Games of 420, sacrificing to the god was the central act of the festival. At Delphi too, the sacrifice should not be seen as a simple preparatory ritual ahead of the consultation, but as an important ritual activity in its own right. And it clearly had a prominent place in the ancient understanding of the sanctuary (Kurke 2003: 80-90). Delphic sacrificing and feasting is lampooned in a number of passages of old comedy gathered by Athenaeus (4.173b-e), and Aesop is said to have criticised Delphic greed, according to various of the Lives of Aesop. In some narratives of the death of Neoptolemos at Delphi, including for example Pindar, Nemean 7, he is killed by the Delphians in a dispute about the division of sacrificial meat (40-42). In the account of the death narrated by the messenger in Euripides' Andromache (1085-1165), sacrifice is not the reason for his being killed, but the description of Neoptolemos being hacked to death by a crowd of Delphians resembles the description of sacrificial behaviour mocked by Aesop according to a papyrus fragment:

Whenever someone comes to sacrifice to the god, the Delphians stand around the altar, each one carrying a sacrificial knife concealed on his person. And when the priest has slain the victim and skinned it and removed and apportioned the innards, each of those standing around hacks off whatever share he can and departs, so that, on many occasions, the sacrifice himself departs without any share at all (P.Oxy 1800 fr. 2 ii 33-46).

The Delphians kill Neoptolemos by stabbing him from places of concealment, and then when he had fallen, stabbing him again: they are treating him as a sacrificial victim himself. It has been suggested that there was a distinctive form of sacrificial practice at Delphi (Amandry 1939: 203-207; Roux 1966: 569-571; Rougemont 1977: 129), but the evidence for this is limited. There was a proverb which said 'whoever sacrifices at Delphi will have to buy their own dinner' (Plutarch, Moralia 709a): but this is part of the general discourse about Delphic greed, not to be taken too seriously (Naiden 2012).

The association of the sanctuary with sacrifice is an important theme in the Homeric Hymn to Apollo. In this hymn, the poet has the god explain his plan in founding a temple:

Here I am minded to make my beautiful temple as an oracle for humankind, who will ever come in crowds bringing me perfect hecatombs, both those who live in the fertile Peloponnese and those who live in the Mainland and the sea- 
girt islands, wishing to consult me; and I would dispense unerring counsel to them all, issuing oracles in my rich temple. (287-93)

Later, he says to his newly appointed Cretan priests:

O foolish men of misplaced suffering, who want anxiety, hard toil, and heartache! I will give you a simple answer to bear in mind. Each of you must keep a knife in his right hand and keep slaughtering sheep: they will be available in abundance, as many as the thronging people bring for me. Watch over my temple, and welcome the people as they gather here. (532-39)

These passages evoke the idea of Delphi as a place of large-scale sacrifice. The emphasis here appears to be on the benefits to the Delphic priests in terms of food, with the implication of Delphic greed that we have already referred to. But if they are set alongside the passage from the Hymn to Hermes quoted earlier, we can see that there is a further area of potential discontent: that the sacrifices may be accepted, but the sacrificers subsequently get no benefit from the oracle and thus have wasted their money in offering the animals in the first place. It is not only the Delphic priesthood who could be considered to combine greed and unreliability. This was an accusation that could be made against manteis more generally (Flower 2008: 134-135), and is a feature of Aristophanes' depiction of chrēsmologoi in Peace (1045-1126) and Birds (959-991). Pentheus, in Euripides' Bacchae (255-257), accuses Teiresias of watching birds and burnt offerings for a fee, which would normally include a share of the sacrificed animal. The discourse about sacrifice at Delphi, and traditions of Delphic greed, is related to the broader discourse about greedy manteis and the idea that manteis might be unreliable, driven solely by desire for material gain. But in Greek literature in general (with the exception of comedy), manteis who are accused of being unreliable, a category that includes Kalchas and Teiresias, turn out always to have spoken the truth. In the same way, in literature Delphic oracular responses also always turn out to be correct. So, the claims of greed and corruptibility are part of a discourse that ends up reaffirming the authority of the god, his oracle and his prophets.

For the Athenian theōroi, whose expenses were in any case covered by the city, participating in the sacrifice and enjoying the entertainment that would have been part of the festival activities are likely to have been memorable and pleasant experiences. But it is worth also saying something about the experience of the consultation of the oracle itself. The working of the oracle itself was an extraordinary event. It can be understood as an example of epiphany, or a theophany, that is, the physical manifestation of a god in the mortal realm. There has been debate, from antiquity onwards, about exactly how the god communicated with mortals, but there was no disagreement that he did (Maurizio 1995). When referring to the delivery of an oracle, the usual formula was 'the god (or Apollo) spoke' (Fontenrose 1978: 212). There were very few sanctuaries where a divinity demonstrated their presence so clearly. We know surprisingly little about the mechanism of most Greek oracles: there is no agreement about the mechanism of the oracle of Zeus at Dodona, for example, despite its significance, and the large corpus of questions known from the site (Eidinow 2007: 67-71; Georgoudi 2012; Parker 2016). It is clear nonetheless 
that the presence of an inspired speaker like the Pythia was by no means usual in the classical period, although it may have become more normal later (Bowden 2013). More common were oracles that worked through the incubation of dreams (Hermes 1996: 160-179), or through the consultation of the entrails of sacrificial victims, as was the practice at Olympia and the oracle of Apollo Ismenios at Thebes (Herodotus 8.134.1). But dreams and sacrifices could occur outside sanctuaries too. At Delphi, the Pythia was visibly possessed by Apollo, and the words of the god could be heard by all present in the adyton of the temple. Plutarch (Moralia 398a) talks of the god being 'confined once a month in the body of a mortal'. This kind of direct intervention in the mortal world was not a normal occurrence, and it is difficult to doubt that it would have had a profound effect on those witnessing it, who would already have been brought to a level of emotional intensity from the procession and sacrifice and the accompanying excitement (Weddle 2017). Although modern scholarship has rightly rejected earlier notions of a wild and frenzied Pythia, intoxicated by subterranean vapours (Fontenrose 1978: 196-197), we should still recognise that consulting the oracle and witnessing the intervention of a god in the mortal world would have been a profoundly moving experience.

\section{Conclusion}

In his Memorabilia (1.4.16), Xenophon has Socrates observe that 'the longest-lasting and wisest of human creations, cities and nations, are those which honour the gods the most'. We have seen, through this exploration of the activities that surrounded the 'political' acts of consulting the Delphic oracle, or voting on matters at the meetings of the Delphic Amphiktyony, that the Athenians recognised this point. The theōroi who were sent by the Athenian assembly spent a significant amount of their time engaged in 'religious' activities: at the Pylaia Athenian pylagorai had seats of honour during the festival; on the days when the oracle was operating, Athenian delegates had a prominent place in the procession to the temple and took part in the central sacrifice. The Athenians could be observed honouring Demeter and Apollo, not only by the other Greeks in attendance, but also by the gods themselves.

The experience of being part of all these festival activities will have had an impact on the theōroi themselves. The Athenian hieromnēmōn and pylagorai will have recognised that their responsibilities at the meeting at Delphi were to Apollo and to his sanctuary. Even if the outcome of debates at Delphi had significant diplomatic implications, they were determined by concerns about the sanctuary-and in 339 BCE specifically the sacred land that was associated with it. Similarly, the men sent by the assembly to consult the oracle will also have found themselves taking part in festival activity, celebrating the god's epiphany. And as at Olympia, where every delegation present took part in the sacrifice to Zeus, but not every city had participants in the games, so at Delphi, being present to honour the god's appearance, and take part in sacrifice, may have been more important than actually asking a question. On the other hand, it was by virtue of their right to consult the oracle that the order of precedence in the procession, and therefore the visible status of the participants, was made clear. So, there were reasons beyond the need to know the 
answer to a question, for the Athenians to send theorroi to the oracle. In particular, to honour the god of prophecy at Delphi would be a way to make it more certain that all the Athenians' divinatory activity would meet with success.

Acknowledgements An earlier draft of this paper was read by Esther Eidinow. I am grateful for her suggestions for improvements to it. All errors remain my own.

Funding No external funding

\section{Compliance with Ethical Standards}

Conflict of interest The author declares that there is no conflict of interest.

Open Access This article is licensed under a Creative Commons Attribution 4.0 International License, which permits use, sharing, adaptation, distribution and reproduction in any medium or format, as long as you give appropriate credit to the original author(s) and the source, provide a link to the Creative Commons licence, and indicate if changes were made. The images or other third party material in this article are included in the article's Creative Commons licence, unless indicated otherwise in a credit line to the material. If material is not included in the article's Creative Commons licence and your intended use is not permitted by statutory regulation or exceeds the permitted use, you will need to obtain permission directly from the copyright holder. To view a copy of this licence, visit http://creativecommons.org/licen ses/by/4.0/.

\section{References}

Amandry, Pierrre. 1939. Convention Religieuse Conclude Entre Delphes et Skiathos. Bulletin de Correspondance Hellénique 63: 183-219.

Amandry, Pierre. 1950. La Mantique Apollinienne à Delphes: Essai sur le Fonctionnement de l'Oracle. Paris: Boccard.

Bowden, Hugh. 2003. The Functions of the Delphic Amphictyony Before 346 BCE. Scripta Classica Israelica 22: 67-83.

Bowden, Hugh. 2004. Xenophon and the Scientific Study of Religion. In Xenophon and His World, ed. Christopher Tuplin, 229-246. Stuttgart: Steiner.

Bowden, Hugh. 2005. Classical Athens and the Delphic Oracle: Divination and Democracy. Cambridge: Cambridge University Press.

Bowden, Hugh. 2013. Seeking Certainty and Claiming Authority: The Consultation of Greek Oracles from the Classical to the Roman Imperial Periods. In Divination in the Ancient World: Religious Options and the Individual. Potsdamer Altertumswissenschaftliche Beiträge, vol. 46, ed. Veit Rosenberger, 41-60. Stuttgart: Steiner.

Bowden, Hugh. 2019. Euxenippos at Oropos: Dreaming for Athens. In Ancient Divination and Experience, ed. Lindsay Driediger-Murphy and Esther Eidinow, 68-86. Oxford: Oxford University Press.

Buckler, John, and Hans Beck. 2008. Central Greece and the Politics of Power in the Fourth Century $B C$. Cambridge: Cambridge University Press.

Chandezon, Christophe. 2000. Foires et Panégyries Dans le Monde Grec Classique et Hellénistique. Revue des études Grecques 113: 70-100.

Compton, Todd. 1994. The Herodotean Mantic Session at Delphi. Rheinisches Museum 137: 217-223.

De Ligt, Luuk. 1993. Fairs and Markets in the Roman Empire. Amsterdam: Gieben.

Derow, Peter, and George Forrest. 1982. An Inscription from Chios. Annual of the British School at Athens 77: 79-92.

Eidinow, Esther. 2007. Oracles, Curses, and Risk Among the Ancient Greeks. Oxford: Oxford University Press.

Flower, Michael. 2008. The Seer in Ancient Greece. Berkeley: University of California Press. 
Fontenrose, Joseph. 1959. Python: A study of the Delphic myth and its origins. Berkeley: University of California Press.

Fontenrose, Joseph. 1978. The Delphic Oracle: Its Responses and Operations. Berkeley: University of California Press.

Garbrah, Kweku. 1986. On the Theophaneia in Chios and the Epiphany of Gods in War. Zeitschrift für Papyrologie und Epigraphik 65: 207-210.

Gawlinski, Laura. 2012. The Sacred Law of Andania: A New Text with Commentary. Berlin: De Gruyter.

Georgoudi, Stella. 2012. Des sons, des signes et des paroles: la divination à l'oeuvre dans l'oracle de Dodone. In La Raison des signes: presages, rits, destin dans les sociétés de la Méditerranée ancienne, ed. Stella Georgoudi, Renée Koch Pierre and Francis Schmidt: 55-90. Leiden: Brill.

Gribble, David. 2012. Alcibiades at the Olympics: Performance, Politics and Civic Ideology. Classical Quarterly 62: 45-71.

Hall, Jonathan. 2014. A History of the Archaic Greek World ca. 1200-479 BCE, 2nd ed. Chichester: Wiley.

Hannah, Robert. 2005. Greek and Roman Calendars: Constructions of Time in the Classical World. London: Duckworth.

Hermes, Laura. 1996. Traum und Traumdeutung in der Antike. Zürich: Artemis and Winkler.

Hornblower, Simon. 2004. Thucydides and Pindar: Historical Narrative and the World of Epinikian Poetry. Oxford: Oxford University Press.

Hornblower, Simon. 2007. Did the Delphic Amphiktiony Play a Political Role in the Classical Period? Mediterranean Historical Review 22: 39-56.

Hornblower, Simon. 2010. Thucydidean Themes. Oxford: Oxford University Press.

Jameson, 1994. Theoxenia. In Ancient Greek Cult Practice from the Epigraphical Evidence, ed. Robin Hägg, 35-57. Stockholm: Swedish Institute in Athens.

Kurke, Leslie. 1993. The Economy of Kudos. In Cultural Poetics in Archaic Greece, ed. Carol Dougherty and Leslie Kurke, 131-163. Cambridge: Cambridge University Press.

Kurke, Leslie. 2003. Aesop and the Contestation of Delphic Authority. In The Cultures within Ancient Greek culture: Contact, Conflict, Collaboration, ed. Carol Dougherty and Leslie Kurke, 77-100. Cambridge: Cambridge University Press.

Lefèvre, François. 1991. Remarques sur le Calendrier des Réunions de l'Amphictyonie Pyléodelphique. Bulletin de correspondance hellénique 115: 579-594.

Lefèvre, François. 1998. L'Amphictionie Pyléo-delphique: Histoire et Institutions. Athens: École française d'Athènes.

Lefèvre, François. 2002. Corpus des Inscriptions de Delphes 4: Documents Amphictioniques. Paris: Boccard.

Maurizio, Lisa. 1995. Anthropology and Spirit Possession: A Reconsideration of the Pythia's Role at Delphi. Journal of Hellenic Studies 115: 69-88.

McInerney, Jeremy. 1997. Parnassus, Delphi, and the Thyiades. Greek, Roman and Byzantine Studies 38: 263-283.

McInerney, Jeremy. 1999. The Folds of Parnassus: Land and Ethnicity in Ancient Phokis. Austin: University of Texas Press.

Morgan, Kathryn. 2009. Philosophy at Delphi: Socrates, Sages, and the Circulation of Wisdom. In Apolline Politics and Poetics, ed. Lucia Athanassaki, Richard Martin, and John Miller, 549-568. Athens: European Cultural Centre of Delphi.

Naiden, Fred. 2012. Blessèd are the Parasites. In Greek and Roman Animal Sacrifice: Ancient Victims, Modern Observers, ed. Christopher Faraone and Fred Naiden, 55-83. Cambridge: Cambridge University Press.

Naiden, Fred. 2013. Smoke Signals for the Gods: Ancient Greek Sacrifice from the Archaic Through Roman Periods. New York: Oxford University Press.

Parke, Herbert, and Donald Wormell. 1956. The Delphic Oracle, vol. 2. Oxford: Blackwell.

Parker, Robert. 2007. Religion and Polytheism at Athens. Oxford: Oxford University Press.

Parker, Robert. 2016. Seeking Advice from Zeus at Dodona. Greece and Rome 63: 69-90.

Petridou, Georgia. 2016. Divine Epiphany in Greek Literature and Culture. Oxford: Oxford University Press.

Pfister, Friedrich. 1934a. Theophania. In Paulys Realencyclopädie der classischen Altertumswissenschaft V A, 2: 2133. Stuttgart: Metzler. 
Pfister, Friedrich. 1934b. Theoxenia. In Paulys Realencyclopädie der classischen Altertumswissenschaft V A, 2: 2256-2258. Stuttgart: Metzler.

Robertson, Noel. 1978. The Myth of the First Sacred War. Classical Quarterly 28: 38-73.

Rougemont, Georges. 1977. Corpus des Inscriptions de Delphes 1: Lois Sacrées et Règlements Religieux. Paris: Boccard.

Roux, Georges. 1966. A Propos d'un Livre Nouveau: Le Calendrier d'Eleusis et l'offrande Pour la Table Sacrée Dans le Culte d'Apollon Pythien. L'antiquité Classique 35: 562-573.

Rutherford, Ian. 2013. State Pilgrims and Sacred Observers in Ancient Greece: A Study of Theōriā and Theōroi. Cambridge: Cambridge University Press.

Sánchez, Pierre. 2001. L'Amphictionie des Pyles et de Delphes. Recherches sur Son Rôle Historique des Origines au IIe Siècle de Notre ère. Stuttgart: Steiner.

Scott, Michael. 2010. Delphi and Olympia: The Spatial Politics of Panhellenism in the Archaic and Classical Periods. Cambridge: Cambridge University Press.

Scott, Michael. 2014. Delphi: A History of the Center of the Ancient World. Princeton: Princeton University Press.

Versnel, Henk. 1998. Inconsistencies in Greek and Roman Religion, Volume 1. Ter unus. Isis, Dionysos, Hermes. Three Studies in Henotheism. Leiden: Brill.

Weddle, Candace. 2017. Blood, Fire and Feasting: The Role of Touch and Taste in Graeco-Roman Animal Sacrifice. In Senses of the Empire: Multisensory Approaches to Roman Culture, ed. Eleanor Betts, 104-120. London: Routledge.

Hugh Bowden is Professor of Ancient History at King's College London. 